\title{
SYNTHESIS OF BIPHENYLTRIENES AS PROBES FOR $\beta$-AMYLOID PLAQUES
}

\author{
Zhi-Ping Zhuang $^{1}$, Mei-Ping Kung ${ }^{1}$, and Hank F. Kung ${ }^{1,2}$ \\ 1 Departments of Radiology, University of Pennsylvania \\ 2 Department of Pharmacology, University of Pennsylvania
}

\begin{abstract}
We report a series of $p$-hydroxy, $p$-amino, $p$-monomethylamino and $p$-monofluoroethylamino substituted biphenyltrienes $(\mathbf{1 4 c}, 14 \mathrm{e}, 14 \mathrm{f}$ and $\mathbf{1 4 h})$, which displayed high binding affinities to $\beta$ amyloid $(\mathrm{A} \beta)$ plaques. In an in vitro binding assay using postmortem brain homogenates of Alzheimer's patients and $\left[{ }^{125} \mathrm{I}\right] 9$, the novel triene compounds showed excellent binding affinities $\left(\mathrm{K}_{\mathrm{i}}=9.0 \pm 2.1,9.0 \pm 3.2,7.5 \pm 2.5\right.$ and $12 \pm 3 \mathrm{nM}$ for $\mathbf{1 4 c}, \mathbf{1 4 e}, \mathbf{1 4 f}$ and $\mathbf{1 4 h}$, respectively $)$. When labeled with suitable radionuclides they are potentially useful as in vivo imaging agents for detecting $\mathrm{A} \beta$ plaques in the brain of patients with Alzheimer's disease.
\end{abstract}

\section{Keywords}

binding affinity; Alzheimer's disease; imaging; $\mathrm{A} \beta$ peptides

\section{INTRODUCTION}

Alzheimer's disease (AD) is a neurodegenerative disease affecting millions in the older population. Common clinical symptoms of AD include cognitive decline, irreversible memory loss, disorientation, language impairment, etc. Major neuropathology observations of postmortem $\mathrm{AD}$ brain include the presence of senile plaques, neurofibrillary tangles and neurophil threads containing $\beta$-amyloid (A $\beta$ ) aggregates and highly phosphorylated tau proteins. ${ }^{1}$ The exact mechanisms leading to the development of AD are not fully understood; however, formation of $A \beta$ plaques in the brain is a pivotal event in the pathology of Alzheimer's disease. Significant circumstantial evidence suggests that fibrillary A $\beta$ plaques consisting predominately of aggregates of $A \beta 40$ and $A \beta 42$ peptides play a major role in AD pathogenesis. ${ }^{2}$ Formation of $A \beta$ aggregates in the brain is now considered as a significant event, which produces various toxic effects in neuronal cells leading to the formation of neuritic plaques. ${ }^{2}$ In view of the critical roles $\mathrm{A} \beta$ plaques play in $\mathrm{AD}, \mathrm{A} \beta$-plaque-specific imaging agents may be useful for early detection or monitoring the progression and effectiveness of treatment of $\mathrm{AD}^{3-5}$

Several research groups have reported $A \beta$ plaque-specific imaging agents based on highly conjugated dyes, such as Congo Red and Chrysamine G. 6,7 Thioflavin T, 5, as well as Congo Red have been used in fluorescent staining of plaques and tangles in postmortem AD brain sections. ${ }^{8}$ More abbreviated forms of Chrysamine G, such as syrylbeneze - including 1-4 (Fig. 1), have been reported as fluorescent dyes for staining amyloid aggregates. ${ }^{9,10}$ Although these

Corresponding author: Hank F. Kung, Ph.D., Department of Radiology, University of Pennsylvania, Room 305, 3700 Market Street, Philadelphia, PA 19104. Tel: (215) 662-3096; Fax: (215) 349-5035; E-mail: kunghf@ sunmac.spect.upenn.edu. 
molecules displayed desirable properties: highly conjugated, high binding affinity and moderate lipophilicity, their partial charge prevents them from getting across the intact bloodbrain barrier (BBB). A recent report has suggested that it may be possible to prepared near infrared fluorescent imaging agents for imaging the plaques inside the brain. ${ }^{11}$

To overcome the observed brain penetration deficit associated with the styrylbenzene series (1-4), we and others focused on benzothiazole and other backbone structures. Recently, successful uses of a $\mathrm{C}-11$ labeled benzothiazole derivative, $\left[{ }^{11} \mathrm{C}\right] \mathrm{PIB}, \mathbf{8}$, and a highly lipophilic F-18 labeled probe, $\left[{ }^{18} \mathrm{~F}\right] \mathrm{FDDNP}, \mathbf{1 0}$, for plaque and tangle visualization in living AD patients have demonstrated the potential usefulness of in vivo plaque imaging. ${ }^{12,13}$ Parallel to these efforts, we have similarly prepared $\left[{ }^{11} \mathrm{C}\right] \mathrm{SB}-13,7$, a stilbene derivative, for plaque imaging. 14 As expected, $\left[{ }^{11} \mathrm{C}\right] \mathrm{SB}-13,7$, displayed high accumulation in the affected cortical areas of the brain in mild to moderate $\mathrm{AD}$ patients, but not in the age-matched control subjects. ${ }^{15}$

In order to investigate the significance of distance between the two phenyl groups of the stilbenes, we have added additional double bonds (trienes), instead of one vinyl for the stilbenes. None of the previously reported ligands contains a highly conjugated polyene backbone. To our surprise the addition of a triene bond between the biphenyl groups produce highly selective compounds showing excellent binding affinity towards homogentes of brain tissues from $\mathrm{AD}$ patients. Reported herein are syntheses and the structure-activity relationship of a series of derivatives as selective probes potentially useful for detecting amyloid aggregates in the brain.

\section{RESULTS AND DISCUSSION}

\section{Chemistry}

The key step for the synthesis of biphenyltrienes is the Wittig reaction between various aldehydes $\mathbf{1 3}$ and bisdiethyl phosphonate, 12, which was readily prepared from 1,4-dibromo (or chloro)-2-butene (Scheme 1). The Wittig reagents, $\mathbf{1 2}$ and various aldehydes, 13, were readily reacted in the presence of $\mathrm{NaH}$ and THF under a refluxing condition. ${ }^{16,17}$ The hydroxyl phenyl triene $\mathbf{1 4 c}$ was obtained from hydrolysis of the MEM protected precursor $\mathbf{1 4 b}$. The bisamino compound $14 \mathrm{e}$ and bismonomethylamino compound $14 \mathrm{f}$ were synthesized from the correspondent nitro compound $\mathbf{1 4 d}$ through reduction and monomethylation. The bis- $p$ - $(\mathrm{N}, \mathrm{N}-$ dimethylamino) derivative, 14g, was prepared directly through the Wittig reaction between the $p$-(N,N-dimethylamino)benzaldehyde 13e and the bisdiethyl phosphonate, 12. One unsymmetrically substituted derivative, N-monofluoroethyl compound, $\mathbf{1 4 h}$, was prepared by reacting the di-amino derivative, 14e, with 1-bromo-2-fluoroethane in the presence of potassium carbonate in DMF.

\section{In vitro Binding of $A \beta$ plaques in $A D$ brain tissue homogenates}

Using in vitro binding of preformed $A \beta$ peptide aggregates and two different ligands, $\left[{ }^{125} \mathrm{I}\right]$ (E,E)-1-iodo-2,5-bis-(3-hydroxycarbonyl-4-methoxy)styrylbenzene, $\left[{ }^{125} \mathrm{I}\right] 4$, and [ $\left.{ }^{125} \mathrm{I}\right] 2$-[4'dimethyl-aminophenyl]-6-iodobenzothiazole, $\left[{ }^{125} \mathrm{I}\right] \mathbf{6}$, it was demonstrated that there are at least two mutually exclusive binding sites on these aggregates. ${ }^{18}$ It has been reported recently from our laboratory that $\left[{ }^{125} \mathrm{I}\right]$ 2-(4'-dimethylaminophenyl)-6-iodo-imidazo[1,2-a]pyridine, $\left[{ }^{125} \mathrm{I}\right] 9$, binds to the same binding sites as those for 6 in transgenic mice as well as in postmortem homogenates of $\mathrm{AD}$ brain tissues, and $\mathbf{9}$ has a better in vivo biodistribution profile as an imaging agent. ${ }^{18-20}$ Specific in vitro binding of $\left[{ }^{125} \mathrm{I}\right] 9$ can be clearly measured in the cortical gray matter, but not in the white matter of AD cases. The location and density of specific signal detected by $\left[{ }^{125} \mathrm{I}\right] \mathbf{9}$ correlated with the distribution of amyloid plaques in these brain specimens, as confirmed by thioflavin-S staining. 
In this study we have extended the in vitro binding assay to using homogenates of AD brain tissue and the two ligands for two different and mutually exclusive binding sites using two different radiolabeled ligands, $\left[{ }^{125} \mathrm{I}\right] \mathbf{4}$ and $\left[{ }^{125} \mathrm{I}\right] \mathbf{9}$ (Table 1). It was demonstrated that the new biphenyltrienes showed variable binding affinities depending on the substitution groups at the $p$-position of the phenyl groups. Generally, the biphenyltrienes preferentially bind to the binding sites for 9 . Specifially, compounds 14c, 14e, 14f and 14h containing substitution groups, - $\mathrm{OH}$, - $\mathrm{NH} 2$, -NHMe and $-\mathrm{NH}\left(\mathrm{CH}_{2} \mathrm{CH}_{2} \mathrm{~F}\right)$ displayed moderate binding affinities towards [ $\left.{ }^{125} \mathrm{I}\right] 4$ giving $\mathrm{K}_{\mathrm{i}}$ values of $150,375,122$ and $217 \mathrm{nM}$, respectively. However, these four compounds exhibited highly potent binding towards $\left[{ }^{125} \mathrm{I}\right] 9$ showing $\mathrm{K}_{\mathrm{i}}$ values of 9.0, 9.0, 7.5 and $12 \mathrm{nM}$, respectively. The binding data suggest that the biphenyltrienes are highly competitive to the binding sites of 9 on the $A \beta$ aggregates, while the binding towards the binding sites for 4 are 15-50 fold lower in affinity. It is expected that the compound with a $\left[{ }^{18} \mathrm{~F}\right]$ fluoroethyl group on $\mathbf{1 4 h}$ can be prepared and the labeled $\left[{ }^{18} \mathrm{~F}\right] \mathbf{1 4 h}$ may be useful as a PET imaging agent specifically targeting $\mathrm{A} \beta$ plaques in the brain.

There are several unexpected findings for this series of compounds. There is a dramatic difference between -OMe, 14a, and -OH, 14c, in binding affinities (>4,000 vs $9.0 \mathrm{nM}$ using $\left[{ }^{125} \mathrm{I}\right] 9$ and $>8,000 \mathrm{vs} 150 \mathrm{nM}$ using $\left.\left[{ }^{125} \mathrm{I}\right] 4\right)$. Addition of the methyl group significantly reduces the binding affinities to both binding sites. The same dramatic difference is observed between -NHMe, 14f, and $-\mathrm{NMe}_{2}, \mathbf{1 4 g}$, in binding affinities (7.5 vs $837 \mathrm{nM}$ using [ $\left.{ }^{125} \mathrm{I}\right] \mathbf{9}$ and 122 vs $>7,000 \mathrm{nM}$ using $\left[{ }^{125} \mathrm{I}\right] 4$ ). It is a striking difference in binding affinity between two seemingly related compounds; $14 \mathrm{f}$ has a mono-N-methylamino and $\mathbf{1 4 g}$ has a $\mathrm{N}, \mathrm{N}$-dimethylamino substitution at the $p$-position of the phenyl rings. In the same assay system, as expected, nonradioactive 9 showed a high binding affinity towards $\left[{ }^{125} \mathrm{I}\right] 4$ binding $\left(\mathrm{K}_{\mathrm{i}}=5.1 \mathrm{nM}\right)$, while it displayed a very low binding affinity to the $\left[{ }^{125} \mathrm{I}\right] 9$ sites suggesting that there are two distinct biding sites. Both 9 and 7 showed strong competitive binding to $\left[{ }^{125} \mathrm{I}\right] \mathbf{9}$ binding sites $\left(\mathrm{K}_{\mathrm{j}}=5.0\right.$ and $1.2 \mathrm{nM}$, respectively). The results are consistent with previously reported values. 18 Recently, 8 has been tested in AD patients as a $A \beta$ plaque-specific imaging agent. ${ }^{13}$ It has been reported previously that $\left[{ }^{3} \mathrm{H}\right] \mathbf{8}$ binds to thehomogenates of postmortem AD brain tissue with a high binding affinity $\left(\mathrm{K}_{\mathrm{d}}=1.4 \mathrm{nM}\right) .{ }^{3}$ In our laboratory competition of 8 to $\left[{ }^{125} \mathrm{I}\right] \mathbf{9}$ binding sites showed a measured $\mathrm{K}_{\mathrm{i}}$ value of $2.8 \mathrm{nM}$, which is comparable to that reported previously. It was also observed that in our study another PET imaging agent, 10, which binds to plaques as well as tangles, however showed a moderate binding affinity towards the $\left[{ }^{125} \mathrm{I}\right]$ 9 binding site $\left(\mathrm{K}_{\mathrm{i}}=152 \mathrm{nM}\right){ }^{18,19}$ indicating 10 might not compete with [ $\left.{ }^{125} \mathrm{I}\right] \mathbf{9}$ for identical binding pockets on amyloid plaques. There may be a third binding site not related to 4 or 9 . This observation has not been reported previously. Significantly, the multiple binding sites on the $\mathrm{A} \beta$ plaques in human $\mathrm{AD}$ brain may be important and should be carefully considered in the future in developing in vivo imaging agents.

In summary, results of the binding study suggest that this series of novel ligands based on biphenyltrienes showed potent binding towards $\mathrm{A} \beta$ plaques in human AD brain tissue homogenates. The competitive binding study showed excellent binding affinities with biphenyltrienes containing - $\mathrm{OH},-\mathrm{NH}_{2},-\mathrm{NHMe}$ and $-\mathrm{NH}\left(\mathrm{CH}_{2} \mathrm{CH}_{2} \mathrm{~F}\right)$ groups. When labeled with suitable short-lived radionuclides they may be useful as imaging agents for detecting amyloid aggregates in the living human brain.

\section{EXPERIMENTAL}

Reagents used in the synthesis were purchased from Aldrich Co. or Fluka Co., and were used without further purification unless otherwise indicated. Anhydrous $\mathrm{Na}_{2} \mathrm{SO}_{4}$ was used as a drying agent. ${ }^{1} \mathrm{H}$ NMR spectra were obtained on a Bruker spectrometer (Bruker AC 200). Chemical shifts are reported as $\delta$ values with chloroform as the internal reference unless otherwise mentioned. Coupling constants are reported in Hz. The multiplicity is defined by s 
(singlet), $\mathrm{d}$ (doublet), $\mathrm{t}$ (triplet), br (broad) and $\mathrm{m}$ (multiplet). PTLC : Preparative Thin Layer Chromatography, silica gel, GF, 2000 microns from Analtech Inc. Elemental Analysis was performed by Atlantic Microlab, Inc.

\section{General procedure for Wittig reaction}

1,6-Bis(4'-methoxyphenyl)-hexa-1,3,5-triene (14a)-To a suspension of $\mathrm{NaH}$ (60 mg, $60 \%$ in mineral oil, $1.5 \mathrm{mmol})$ in THF $(5 \mathrm{~mL})$ was added a solution of tetraethyl-2-butene-1,4diphosphonate (12) $(164 \mathrm{mg}, 0.5 \mathrm{mmol})$ in THF $(5 \mathrm{~mL})$ dropwise followed by a solution of 4methoxybenzaldehyde $(136 \mathrm{mg}, 1 \mathrm{mmol})$ in THF $(10 \mathrm{~mL})$. The mixture was stirred under reflux overnight. Isopropyl alcohol was added to destroy the excesses of $\mathrm{NaH}$ after cooling. Ice-water was added and the precipitate was collected by suction, washed with water and dried. The crude product was recrystallized in benzene to afford $34 \mathrm{mg}$ of product (m.p. $244-245^{\circ} \mathrm{C}, 23 \%$ ).

${ }^{1} \mathrm{HNMR}\left(200 \mathrm{MHz}, \mathrm{CDCl}_{3}\right): \delta 3.81(\mathrm{~s}, 6 \mathrm{H}), 6.46(\mathrm{~s}, 2 \mathrm{H}), 6.52(\mathrm{~d}, J=15.6 \mathrm{~Hz}, 2 \mathrm{H}), 6.74(\mathrm{~m}$, $2 \mathrm{H}), 6.85(\mathrm{~d}, J=8.5 \mathrm{~Hz}, 4 \mathrm{H}), 7.34(\mathrm{~d}, J=8.7 \mathrm{~Hz}, 4 \mathrm{H})$.

$\operatorname{Anal}\left(\mathrm{C}_{20} \mathrm{H}_{20} \mathrm{O}_{2}\right) \mathrm{H}$; C: calcd, 82.16; found, 81.24.

1,6-Bis[4'-(2"-methox-ethoxy)-methoxyphenyl]-hexa-1,3,5-triene (14b)-

Prepared as described above from 4-(2'-methoxyethoxy-)methoxy-benzaldehyde (13c, $2.1 \mathrm{~g}$, $10 \mathrm{mmol})$ and $12(1.64 \mathrm{~g}, 5 \mathrm{mmol})$ to afford $1.18 \mathrm{~g}$ of product $(29 \%)$.

${ }^{1} \mathrm{HNMR}\left(200 \mathrm{MHz}, \mathrm{CDCl}_{3}\right): \delta 3.37$ (s, 6H), $3.33(\mathrm{~m}, 4 \mathrm{H}), 3.81(\mathrm{~m}, 4 \mathrm{H}), 5.28(\mathrm{~s}, 4 \mathrm{H}), 6.45$ $(\mathrm{d}, \mathrm{d}, J=6.9,2.8 \mathrm{~Hz}, 2 \mathrm{H}), 6.51(\mathrm{~d}, J=15.5 \mathrm{~Hz}, 2 \mathrm{H}), 6.76(\mathrm{~d}, \mathrm{~d}, \mathrm{~d}, J=15.5,7.0,3.2 \mathrm{~Hz}, 2 \mathrm{H})$, $7.00(\mathrm{~d}, J=8.7 \mathrm{~Hz}, 4 \mathrm{H}), 7.33(\mathrm{~d}, J=8.7 \mathrm{~Hz}, 4 \mathrm{H})$.

$\operatorname{Anal}\left(\mathrm{C}_{26} \mathrm{H}_{32} \mathrm{O}_{6}\right) \mathrm{C}, \mathrm{H}$.

1,6-Bis(4'-nitrophenyl)-hexa-1,3,5-triene (14d)—Prepared as described above from 4nitro-benzaldehyde (302 mg, $2 \mathrm{mmol})$ and $\mathbf{1 2}(328 \mathrm{mg}, 1 \mathrm{mmol})$ to afford $200 \mathrm{mg}$ of product $(62 \%)$.

${ }^{1} \mathrm{HNMR}\left(200 \mathrm{MHz}, \mathrm{CDCl}_{3}\right): \delta 6.64(\mathrm{~d}, \mathrm{~d}, J=7.0,3.0 \mathrm{~Hz}, 2 \mathrm{H}), 6.70(\mathrm{~d}, J=15.6 \mathrm{~Hz}, 2 \mathrm{H}), 7.04$ $(\mathrm{d}, \mathrm{d}, \mathrm{d}, J=15.4,7.0,2.9 \mathrm{~Hz}, 2 \mathrm{H}), 7.54(\mathrm{~d}, J=8.8 \mathrm{~Hz}, 4 \mathrm{H}), 8.19(\mathrm{~d}, J=8.8 \mathrm{~Hz}, 4 \mathrm{H})$.

$\operatorname{Anal}\left(\mathrm{C}_{18} \mathrm{H}_{14} \mathrm{~N}_{2} \mathrm{O}_{4}\right) \mathrm{C}, \mathrm{H}, \mathrm{N}$.

1,6-Bis(4'-dimethylaminophenyl)-hexa-1,3,5-triene (14g)-Prepared as described above from 4-dimethyaminobenzaldehyde (149 mg, $1 \mathrm{mmol})$ and $12(164 \mathrm{mg}, 0.5 \mathrm{mmol})$ to afford $60 \mathrm{mg}$ of product (38\%).

${ }^{1} \mathrm{HNMR}\left(200 \mathrm{MHz}, \mathrm{CDCl}_{3}\right): \delta 2.97(\mathrm{~s}, 12 \mathrm{H}), 6.42(\mathrm{~d}, \mathrm{~d}, J=6.9,2.9 \mathrm{~Hz}, 2 \mathrm{H}), 6.47(\mathrm{~d}, J=13.8$ $\mathrm{Hz}, 2 \mathrm{H}), 6.68(\mathrm{~d}, J=8.8 \mathrm{~Hz}, 4 \mathrm{H}), 6.70(\mathrm{~m}, 2 \mathrm{H}), 7.30(\mathrm{~d}, J=8.9 \mathrm{~Hz}, 4 \mathrm{H})$.

$\operatorname{Anal}\left(\mathrm{C}_{22} \mathrm{H}_{26} \mathrm{~N}_{2}\right) \mathrm{C}$ : calcd, 82.97; found, 76.55; H: calcd, 8.23; found, 8.65; N: calcd, 8.8; found, 7.89 .

4-(2'-methoxyethoxy-)methoxybenzaldehyde (13c)-To a solution of 4hydroxybenzaldehyde $(3.7 \mathrm{~g}, 30 \mathrm{mmol})$ and diisopropylethylamine $(7.6 \mathrm{~mL})$ in $\mathrm{CH}_{2} \mathrm{Cl}_{2}(60$ $\mathrm{mL}$ ) was added $\mathrm{MEMCl}(5.0 \mathrm{~mL})$ in $\mathrm{CH}_{2} \mathrm{Cl}_{2}(17 \mathrm{~mL})$ dropwise at $0^{\circ} \mathrm{C}$. The mixture was stirred at $\mathrm{RT}$ for $3 \mathrm{~h}$, quenched with $\mathrm{HCl}(60 \mathrm{~mL}, 0.5 \underline{\mathrm{N}})$. The mixture was extracted with $\mathrm{CH}_{2} \mathrm{Cl}_{2}$. The organic phase was washed with $\mathrm{NaOH}$ solution $(1 \underline{\mathrm{N}})$ and water. The separated organic 
phase was dried under $\mathrm{Na}_{2} \mathrm{SO}_{4}$, filtered and concentrated to give $6.2 \mathrm{~g}$ of product (97\%), which was pure enough to be used to the next reaction without further purification.

${ }^{1} \mathrm{HNMR}\left(200 \mathrm{MHz}, \mathrm{CDCl}_{3}\right): \delta 3.36(\mathrm{~s}, 3 \mathrm{H}), 3.54(\mathrm{~m}, 2 \mathrm{H}), 3.83(\mathrm{~m}, 2 \mathrm{H}), 5.41(\mathrm{~s}, 2 \mathrm{H}), 7.16(\mathrm{~d}$, $J=8.7 \mathrm{~Hz}, 2 \mathrm{H}), 7.83(\mathrm{~d}, J=8.7 \mathrm{~Hz}, 2 \mathrm{H}), 9.90(\mathrm{~s}, 1 \mathrm{H})$.

1,6-Bis(4'-hydroxyphenyl)-hexa-1,3,5-triene (14c)-To a solution of compound $14 \mathrm{~b}$ $(237 \mathrm{mg}, 0.54 \mathrm{mmol})$ in a mixed solvent $(15 \mathrm{~mL}$, THF:MeOH $=2: 1)$ was added $\mathrm{HCl}$ ( $2 \mathrm{~mL}$, conc.). The mixture was stirred at RT overnight. Water was added and the mixture was extracted with ethyl acetate. Usually work up gave crude product which was purified by PTLC (Hex:EA $=2: 1$ as developing solvent) to give $44 \mathrm{mg}$ of product (31\%).

${ }^{1} \mathrm{HNMR}\left(200 \mathrm{MHz}, \mathrm{CDCl}_{3}\right.$ ): $\delta 6.44$ (d,d, $\left.J=6.7,2.7 \mathrm{~Hz}, 2 \mathrm{H}\right), 6.49(\mathrm{~d}, J=14.5 \mathrm{~Hz}, 2 \mathrm{H}), 6.70$ $(\mathrm{m}, 2 \mathrm{H}), 6.75(\mathrm{~d}, J=8.6 \mathrm{~Hz}, 4 \mathrm{H}), 7.27(\mathrm{~d}, J=8.6 \mathrm{~Hz}, 4 \mathrm{H}), 7.55(\mathrm{~s}, 2 \mathrm{H})$.

$\operatorname{Anal}\left(\mathrm{C}_{18} \mathrm{H}_{16} \mathrm{O}_{2} \cdot 1 / 2 \mathrm{H}_{2} \mathrm{O}\right) \mathrm{C}, \mathrm{H}$.

1,6-Bis(4'-aminophenyl)-hexa-1,3,5-triene (14e)—A mixture of compound 14d (180 $\mathrm{mg}, 0.56 \mathrm{mmol})$ and $\mathrm{SnCl}_{2}(1.05 \mathrm{~g})$ in $\mathrm{EtOH}(20 \mathrm{~mL})$ was refluxed overnight. Water was added and the mixture was made basic with $\mathrm{NaOH}$ solution $(40 \%)$. The mixture was extracted with EA. The separated organic phase was dried under $\mathrm{Na}_{2} \mathrm{SO}_{4}$, filtered and concentrated to give crude product which was purified by PTLC (Hexane:Ethylacetate $=1: 1$ ) to give $50 \mathrm{mg}$ of product (34\%).

${ }^{1} \mathrm{HNMR}\left(200 \mathrm{MHz}, \mathrm{CDCl}_{3}\right): \delta 6.39$ (d,d, $\left.J=7.0,3.0 \mathrm{~Hz}, 2 \mathrm{H}\right), 6.44(\mathrm{~d}, J=15.2 \mathrm{~Hz}, 2 \mathrm{H}), 6.59$ $(\mathrm{d}, J=8.5 \mathrm{~Hz}, 4 \mathrm{H}), 6.70(\mathrm{~d}, \mathrm{~d}, \mathrm{~d}, J=15.5,7.0,3.0 \mathrm{~Hz}, 2 \mathrm{H}), 7.18(\mathrm{~d}, J=8.5 \mathrm{~Hz}, 4 \mathrm{H})$.

$\operatorname{Anal}\left(\mathrm{C}_{18} \mathrm{H}_{18} \mathrm{~N}_{2}\right) \mathrm{H}, \mathrm{N}$; C: calcd, 82.41; found, 80.09.

1,6-Bis(4'-methylaminophenyl)-hexa-1,3,5-triene (14f)-To a suspension of amine $14 \mathbf{e}(15 \mathrm{mg}, 0.06 \mathrm{mmol})$ in $\mathrm{MeOH}(3 \mathrm{~mL})$ was added $\mathrm{NaOMe}(30 \mathrm{mg})$ in solid form followed by $\left(\mathrm{CH}_{2} \mathrm{O}\right)_{\mathrm{n}}(18 \mathrm{mg}, 0.6 \mathrm{mmol})$ in solid form. The mixture was stirred under reflux for $2 \mathrm{~h}$. $\mathrm{NaBH}_{4}(44 \mathrm{mg}, 1.2 \mathrm{mmol})$ was added in portions after the reaction mixture was cooled down. The resulting mixture was stirred under reflux for $1 \mathrm{~h}$. Ice water was added and the mixture was extracted with $\mathrm{CH}_{2} \mathrm{Cl}_{2}$. The organic phase was dried under $\mathrm{Na}_{2} \mathrm{SO}_{4}$, filtered, concentrated and purified by PTLC (Hexane:Ethylacetate $=2: 1$ ) to give $15 \mathrm{mg}$ of product $(90 \%)$.

${ }^{1} \mathrm{HNMR}\left(200 \mathrm{MHz}, \mathrm{CDCl}_{3}\right): \delta 2.85(\mathrm{~s}, 6 \mathrm{H}), 6.40(\mathrm{~d}, \mathrm{~d}, J=6.9,2.9 \mathrm{~Hz}, 2 \mathrm{H}), 6.46(\mathrm{~s}, J=15.6$ $\mathrm{Hz}, 2 \mathrm{H}), 6.55(\mathrm{~d}, J=8.6 \mathrm{~Hz}, 4 \mathrm{H}), 6.68(\mathrm{~m}, 2 \mathrm{H}), 7.26(\mathrm{~d}, J=8.9 \mathrm{~Hz}, 4 \mathrm{H})$.

$\operatorname{Anal}\left(\mathrm{C}_{20} \mathrm{H}_{22} \mathrm{~N}_{2} \cdot \mathrm{H}_{2} \mathrm{O}\right) \mathrm{C}, \mathrm{H}, \mathrm{N}$.

1-(4'-aminophenyl)-6-[4'-(2'-fluoroethylamino)phenyl]-hexa-1,3,5-triene (14h)To a solution of compound $14 \mathrm{e}(30 \mathrm{mg}, 0.11 \mathrm{mmol})$ and 1-bromo-2-fluoroethane (100 $\mathrm{mg}$, $0.78 \mathrm{mmol})$ in DMF ( $3 \mathrm{~mL}$ ) was added $\mathrm{K}_{2} \mathrm{CO}_{3}(160 \mathrm{mg}$, $5 \mathrm{eq})$ and $\mathrm{KI}(5 \mathrm{mg})$. The mixture was stirred at $90^{\circ} \mathrm{C}$ overnight. Water was added and the mixture was extracted with $\mathrm{CH}_{2} \mathrm{Cl}_{2}$. The solvent was removed and the residue was purified by PTLC (Hexane:Ethylacetate $=2: 1$ ) to give $7 \mathrm{mg}$ of product $(20 \%)$.

${ }^{1} \mathrm{HNMR}\left(200 \mathrm{MHz}, \mathrm{CDCl}_{3}\right): \delta 3.45(\mathrm{t}, \mathrm{d}, J=26.6,4.5 \mathrm{~Hz} 2 \mathrm{H}), 4.62(\mathrm{t}, \mathrm{d}, J=47.3,4.5 \mathrm{~Hz}, 2 \mathrm{H})$, 6.27-6.67 (m, $10 \mathrm{H}), 7.20-7.34(\mathrm{~m}, 4 \mathrm{H})$.

$\operatorname{Anal}\left(\mathrm{C}_{20} \mathrm{H}_{21} \mathrm{FN}_{2}\right) \mathrm{H}$; C: calcd, 77.89; found, 74.04; N: calcd, 9.08; found, 8.41. 


\section{Preparation of radioiodinated ligands}

The desired ${ }^{125}$ I labeled ligands, 9 and $\mathbf{4}$, were prepared using iododestannylation reactions. Hydrogen peroxide ( $50 \mu \mathrm{L}, 3 \% \mathrm{w} / \mathrm{v}$ ) was added to a mixture of $50 \mu \mathrm{L}$ of the correspondent tributyltin precursor $(1 \mu \mathrm{g} / \mu \mathrm{L} \mathrm{EtOH}), 50 \mu \mathrm{L}$ of $1 \mathrm{~N} \mathrm{HCl}$ and $\left[{ }^{125} \mathrm{I}\right] \mathrm{NaI}(1-5 \mathrm{mCi})$ in a closed vial. The reaction was allowed to proceed for $10 \mathrm{~min}$ at room temperature and terminated by addition of $100 \mu \mathrm{L}$ of sat. $\mathrm{NaHSO}_{3}$. The reaction mixture was either directly extracted (styrylbenzenes) with ethyl acetate $(3 \times 1 \mathrm{~mL})$ or extracted after neutralization with saturated sodium bicarbonate solution (thioflavins). The combined extracts were evaporated to dryness. For styrylbenzenes the residues were dissolved in $100 \mu \mathrm{L}$ of EtOH and purified by HPLC using a reversed phase column (Waters $\mu$ bondpad, $3.9 \times 300 \mathrm{~mm}$ ) with an isocratic solvent of $65 \%$ acetonitrile-35\% trifluoroacetic acid $(0.1 \%)$ in a flow rate of $0.8 \mathrm{~mL} / \mathrm{min}$. $\left.{ }^{125} \mathrm{I}\right] \mathbf{9}$ was purified on a PRP-1 column (Hamilton, $4.1 \times 250 \mathrm{~mm}$ ) eluted with an isocratic solvent of $90 \%$ acetonitrile-10\% 3,3-dimethyl-glutaric acid $(5 \mathrm{mM}, \mathrm{pH} 7.0)$ and a flow rate of $1.0 \mathrm{~mL} / \mathrm{min}$. The desired fractions containing the product were collected, condensed and re-extracted with ethyl acetate. The no-carrier-added products were evaporated to dryness and re-dissolved in $100 \% \mathrm{EtOH}(1 \mu \mathrm{Ci} / \mu \mathrm{L})$. The final ${ }^{125} \mathrm{I}$ probes, with a specific activity of $2,200 \mathrm{Ci} / \mathrm{mmole}$ and a greater than $95 \%$ radiochemical purity, were stored at $-20{ }^{\circ} \mathrm{C}$ up to 6 weeks for in vitro binding studies.

\section{Binding assays using homogenates of AD brain tissue}

Postmortem brain tissues were obtained from AD patients at autopsy, and neuropathological diagnosis was confirmed by current criteria (NIA-Reagan Institute Consensus Group, 1997). Homogenates were then prepared from dissected gray matters from AD patients in phosphate buffered saline (PBS, pH 7.4) at the concentration of approximately $100 \mathrm{mg}$ wet tissue/ml (motor-driven glass homogenizer with setting of 6 for $30 \mathrm{sec}$ ). The homogenates were aliquoted into $1 \mathrm{ml}$-portions and stored at $-70^{\circ} \mathrm{C}$ for 3-6 month without loss of binding signal.

Binding assays were carried out in $12 \times 75 \mathrm{~mm}$ borosilicate glass tubes. For competition studies, the reaction mixture contained $50 \mu \mathrm{l}$ of AD brain tissue homogenates (containing 20-50 $\mu \mathrm{g}$ protein), $50 \mu \mathrm{l}$ of [ $\left.{ }^{125} \mathrm{I}\right] 9$ (diluted in PBS, $0.02-0.04 \mathrm{nM}$ for $\left[{ }^{125} \mathrm{I}\right] 9$ ) and $50 \mu \mathrm{l}$ of inhibitiors $\left(10^{-7}-10^{-10} \mathrm{M}\right.$ diluted serially in PBS containing $0.1 \%$ bovine serum albumin) in a final volume of $1 \mathrm{ml}$. Similarly, $\left[{ }^{125} \mathrm{I}\right] 4$ (diluted in PBS, 0.02-0.04 nM) was used for the binding assay. Nonspecific binding was defined in the presence of $600 \mathrm{nM} \mathrm{9}$, or 4, in the same assay tubes. The mixture was incubated at $37^{\circ} \mathrm{C}$ for $2 \mathrm{hr}$ and the bound and the free radioactivity were separated by vacuum filtration through Whatman GF/B filters using a Brandel M-24R cell harvester followed by $2 \times 3 \mathrm{~mL}$ washes of PBS at room temperature. Filters containing the bound I-125 ligand were counted in a gamma counter (Packard 5000) with 70\% counting efficiency. The results of inhibition experiments were based on the assumption that the compounds under the evaluation competed for the same binding site with the hot ligand and the data were subjected to nonlinear regression analysis with the EBDA and Ligand programs 21 by which $\mathrm{K}_{\mathrm{i}}$ values were calculated.

\section{Supplementary Material}

Refer to Web version on PubMed Central for supplementary material.

\section{Acknowledgements}

This work was supported by grants awarded from the National Institutes of Health (AG022559 H.F.K and AG-21868 M-P. K.), Institute for the Study of Aging (M-P. K.) We thank Dr. George Barrio for kindly providing cold FDDNP for competition study. 


\section{References}

1. Selkoe DJ. Alzheimer disease: mechanistic understanding predicts novel therapies. Ann Intern Med 2004;140:627-38. [PubMed: 15096334]

2. Hardy J, Selkoe DJ. The amyloid hypothesis of Alzheimer's disease: progress and problems on the road to therapeutics. Science 2002;297:353-356. [PubMed: 12130773]

3. Mathis CA, Wang Y, Klunk WE. Imaging b-amyloid plaques and neurofibrillary tangles in the aging human brain. Curr Pharm Des 2004;10:1469-1492. [PubMed: 15134570]

4. Selkoe DJ. Imaging Alzheimer's amyloid. Nat Biotechnol 2000;18:823-824. [PubMed: 10932146]

5. Mathis CA, Klunk WE, Price JC, DeKosky ST. Imaging technology for neurodegenerative diseases: progress toward detection of specific pathologies. Arch Neurol 2005;62:196-200. [PubMed: 15710847]

6. Klunk WE, Debnath ML, Pettegrew JW. Small-molecule beta-amyloid probes which distinguish homogenates of Alzheimer's and control brains. Biol Psychiatry 1994;35:627.

7. Klunk WE, Debnath ML, Koros AM, Pettegrew JW. Chrysamine-G, a lipophilic analogue of Congo red, inhibits A $\beta$-induced toxicity in PC12 cells. Life Sci 1998;63:1807-1814. [PubMed: 9820124]

8. Elhaddaoui A, Pigorsch E, Delacourte A, Turrell S. Competition of congo red and thioflavin S binding to amyloid sites in Alzheimer's diseased tissue. Biospectroscopy 1995;1:351-356.

9. Styren SD, Hamilton RL, Styren GC, Klunk WE. X-34, a fluorescent derivative of Congo Red: a novel histochemical stain for Alzheimer's disease pathology. J Histochem Cytochem 2000;48:1223-1232. [PubMed: 10950879]

10. Link CD, Johnson CJ, Fonte V, Paupard MC, Hall DH, Styren S, Mathis CA, Klunk WE. Visualization of fibrillar amyloid deposits in living, transgenic Caenorhabditis elegans animals using the sensitive amyloid dye, X-34. Neurobiol Aging 2001;22:217-226. [PubMed: 11182471]

11. Hintersteiner M, Enz A, Frey P, Jaton AL, Kinzy W, Kneuer R, Neumann U, Rudin M, Staufenbiel M, Stoeckli M, Wiederhold KH, Gremlich HU. In vivo detection of amyloid-beta deposits by nearinfrared imaging using an oxazine-derivative probe. Nat Biotechnol 2005;23:577-83. [PubMed: 15834405]

12. Agdeppa ED, Kepe V, Liu J, Flores-Torres S, Satyamurthy N, Petric A, Cole GM, Small GW, Huang SC, Barrio JR. Binding characteristics of radiofluorinated 6-dialkylamino-2-naphthylethylidene derivatives as positron emission tomography imaging probes for $\beta$-amyloid plaques in Alzheimer's disease. J Neurosci 2001;21:RC189. [PubMed: 11734604]

13. Klunk WE, Engler H, Nordberg A, Wang Y, Blomqvist G, Holt DP, Bergstrom M, Savitcheva I, Huang G-f, Estrada S, Ausen B, Debnath ML, Barletta J, Price JC, Sandell J, Lopresti BJ, Wall A, Koivisto P, Antoni G, Mathis CA, Langstrom B. Imaging Brain Amyloid in Alzheimer's Disease with Pittsburgh Compound-B. Ann Neurol 2004;55:306-319. [PubMed: 14991808]

14. Ono M, Wilson A, Nobrega J, Westaway D, Verhoeff P, Zhuang ZP, Kung MP, Kung HF. ${ }^{11}$ CLabeled Stilbene Derivatives as A $\beta$-aggregate-specific PET Imaging Agents for Alzheimer's Disease. Nucl Med Biol 2003;30:565-571. [PubMed: 12900282]

15. Verhoeff NP, Wilson AA, Takeshita S, Trop L, Hussey D, Singh K, Kung HF, Kung MP, Houle S. In vivo imaging of Alzheimer disease beta-amyloid with [11C]SB-13 PET. Am J Geriatr Psychiatry 2004;12:584-595. [PubMed: 15545326]

16. Kauffman JM, Moyna G. Diarylamino groups as photostable auxofluors in 2-benzoxazolylfluorene, 2,5-diphenyloxazoles, 1,3,5-hexatrienes, 1,4-distyrylbenzenes, and 2,7-distyrylfluorenes. J Org Chem 2003;68:839-53. [PubMed: 12558406]

17. Chen CH, Doney JJ, Reynolds GA, Saeva FD. New donors with two-electron oxidation. Synthesis and electrochemical properties of highly conjugated bis(4H-thiopyrans) and bis(flavenes). J Org Chem 1983;48:2757-61.

18. Kung MP, Hou C, Zhuang ZP, Skovronsky D, Kung HF. Binding of two potential imaging agents targeting amyloid plaques in postmortem brain tissues of patients with Alzheimer's disease. Brain Res 2004;1025:89-105.

19. Kung MP, Hou C, Zhuang ZP, Cross AJ, Maier DL, Kung HF. Characterization of IMPY as a potential imaging agent for $\beta$-amyloid plaques in double transgenic PSAPP mice. Eur J Nucl Med Mol Imaging 2004;31:1136-1145. [PubMed: 15007564] 
20. Zhuang ZP, Kung MP, Wilson A, Lee CW, Plossl K, Hou C, Holtzman DM, Kung HF. Structureactivity relationship of imidazo[1,2-a]pyridines as ligands for detecting beta-amyloid plaques in the brain. J Med Chem 2003;46:237-243. [PubMed: 12519062]

21. Munson PJ, Rodbard D. LIGAND: a versatile computerized approach for characterization of ligandbinding systems. Anal Biochem 1980;107:220-239. [PubMed: 6254391] 

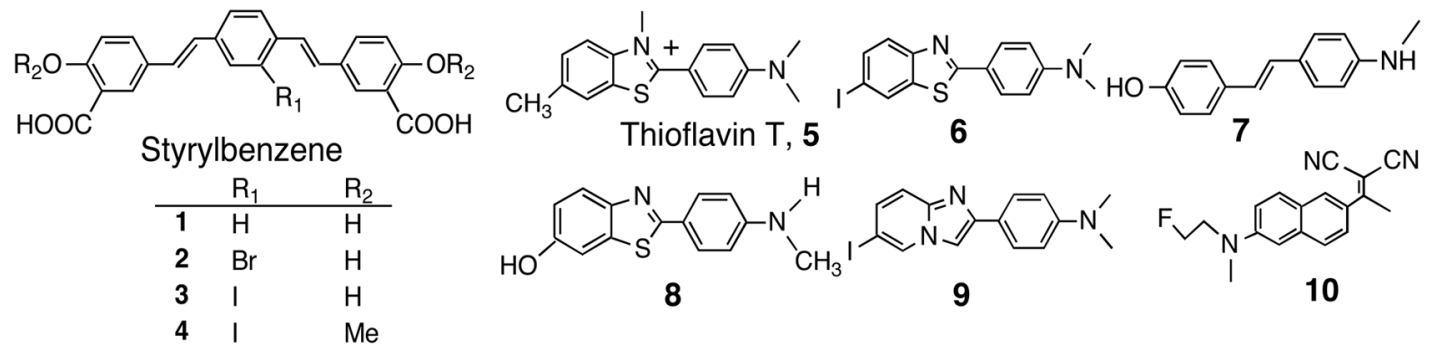

Figure 1.

Chemical structures of various probes for $\mathrm{A} \beta$ aggregates 


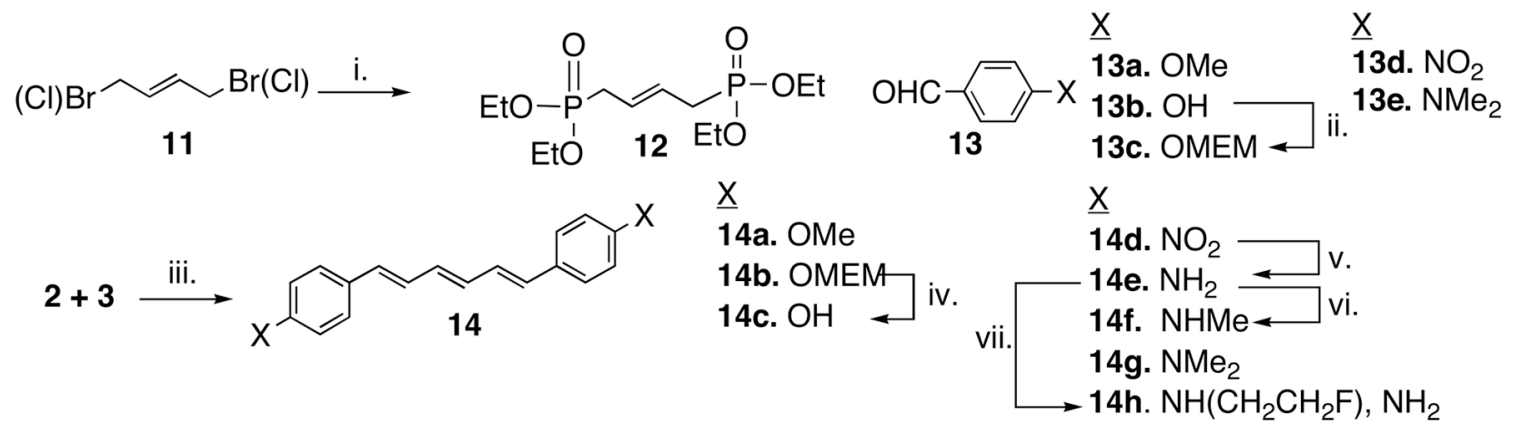

Scheme 1.

i. $\mathrm{P}(\mathrm{OEt})_{3}$; ii. $\mathrm{MEMCl} / \mathrm{DIEA}, \mathrm{CH}_{2} \mathrm{Cl}_{2}$; iii. $\mathrm{NaH}$, THF, Reflux; iv. $\mathrm{HCl}$, THF/MeOH(2:1); v. $\mathrm{SnCl}_{2} / \mathrm{EtOH}$; vi. $\mathrm{NaOMe} /\left(\mathrm{CH}_{2} \mathrm{O}\right)$ n; $\mathrm{NaBH}_{4} / \mathrm{MeOH}$; vii. $\mathrm{BrCH}_{2} \mathrm{CH}_{2} \mathrm{~F}, \mathrm{~K}_{2} \mathrm{CO}_{3} / \mathrm{DMF}$; Except for $\mathbf{4 h}$, all are symmetrical. 


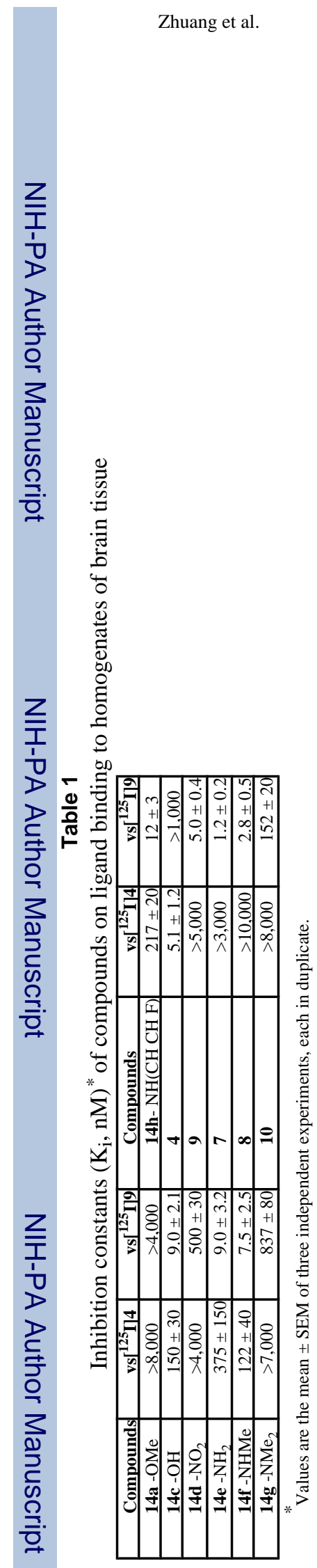

Page 11 